\title{
The Electoral Process and Democratic Consolidation in Nigeria
}

\author{
Nwokeke P. Osinakachukwu (Corresponding author) \\ Dept. of Government and Civilization Studies, Faculty of Human Ecology \\ Putra University, Malaysia \\ Tel: 60-14-334-1857 E-mail: ossypeters@yahoo.com
}

Jayum A Jawan

Dept. of Government and Civilization Studies, Faculty of Human Ecology

Putra University, Malaysia

Tel: 60-19-321-5897Ｅ-mail: jayum@putra.upm.edu.my

Received: December 21, 2010

Accepted: January 20, 2011

doi:10.5539/jpl.v4n2p128

\begin{abstract}
This paper examines election rigging and its effect on democratic consolidation in Nigeria relying on qualitative approach, using data gathered from secondary sources. It will be analyzed via content and historical analysis. Election riggings in Nigeria have dealt a huge blow to the development of democracy in Nigeria. Nigeria's elections so far have not live up to expectations due to various forms of electoral manipulations which have denied the country credible free and fair elections in her body politic. Election rigging has not only marred democratic consolidation in Nigeria but has also violated the fundamental human right (right to life) of so many Nigerians. Election riggings since independence reviewed in this paper will be our bench mark. The study found that election riggings in Nigeria have resulted into the imposition of corrupt and illegitimate leaders who have no regard to the principles of democracy which are off-shoots for good governance, rule of law, constitutionalism and fundamental human rights. This paper provides some important recommendations that would serve as a panacea to the problems of election riggings and how those measures can help necessitate a democratic environment which is a precondition for free and fair elections.
\end{abstract}

Keywords: Democracy, Election rigging, Election, Democratic Consolidation

\section{Introduction}

We are going to look into all the histories of election rigging in Nigeria from 1960 to 2007 and how they have hindered the emergence of democratic consolidation in Nigeria. In a liberal democracy, election is the best option to change government periodically. It does not only promote leadership change, it encourages accountability in leadership. It allows for participation and it helps to reside power to the people. To be precise, elections are the best means to make the sovereign power of the masses known.

Ojie (2006) states that in a democracy, those whose responsibility is to exercise political authorities in a society perform it with the explicit consent and genuine mandate expressed at periodic intervals by the electorate through an open, free and fair electoral process. This implies that democracy must be a system of government where the people dictate the pace with the general consent of the governed. Unfortunately, Nigeria's elections have so far thwarted the foundation upon which democracy is built due to election rigging. Nigeria is in the category where election management is less successful. The rules guiding elections are ambiguous, ever changing or easily maneuvered; the electoral regulations and rules is institutionally less effective; the political bigwigs are the gladiators in their conduct; hence the electorates are often powerless as they live in the mercy of the political stalwarts and political outcomes. The political barons, who have special interest, impose unpopular candidates and employ every form of political gimmick to influence the election in their favours against the general will of the people.

Election riggings in Nigeria were evident in 1964/1965, 1979, 1983,1993,1999,2003 and 2007 general elections. Between 1999 and 2007, election riggings have accompanied with bloodshed and this have claimed the lives of so many Nigerians, especially popular contestants, and these political killings are executed by hired assassins from wicked politicians who want power by all means. The contemporary political barons in Nigeria impose gullible electoral officers who employ various tricks to win election for their employers to the detriment of the masses and popular candidates. This, however, has made the system very boring and many have resorted to stay at home during 
electioneering for fear of being intimidated or coerced to vote against their will and this is too bad for a country that is desperate to institutionalize a consolidated democracy.

\subsection{Nature of the problems}

Nigerian democracy aims to ensure political stability and promote fundamental human rights. Elections in Nigeria which should have been a prelude for achieving a stabilize government accompanied with people's consent have contradicted these standards because of election rigging. This is a serious concern hence the stability and secured environment needed for the success of democracy have been severely jeopardized. Elections conducted since Nigeria's independence have been played in a do or die affair and this has made the peace-loving Nigerians to be dead scared in exercising their voting rights hence the suicidal nature of the politics. Evident has shown that the rate of citizen participation in elections these days have drastically reduced due to the limited choice or lack of qualified candidates. Lacks of candidates with vision have made the electorates politically weak. Sometimes, the electorates are disenfranchised and the alienated political barons employ the use of coercion to seize power or what Ihonvbere (1989) painted in a general picture of Africa's situation as, ruler-ship became permanent, politics became Hobbesian: power was fought by all means and the struggle for power became the overriding worry. Adekanye (1990:2) notes that because of the history of electoral fraud, elections in the country have often been associated with political tension, crisis, and even violence. Actually, politics is seen as the only game in town, and it was played with deadly seriousness for the winner won everything and the loser lost everything.

This quest to win election by all means has also claimed the lives of both the electorates and some popular candidates by some hoodlums who want to control the government by dubious means. As a result, those who have the interest of Nigerians at heart have resorted to shun politics for fear of facing a sudden death in the process and this has posed a serious threat to Nigerian democracy and its consolidation. Worse still, electoral body which would have been neutral, and ensure a free and fair elections have been biased because in some cases, they are employed by some power brokers to serve as a rescue mission to some illegitimate candidates to the detriment of popular candidates and Nigerian electorates. To ensure that their unpopular candidates emerged victorious in elections, they have seen election rigging as a way out against the general wish of the popular candidates, electorates and the good of Nigerian democracy. Kurfi (2005:101) has observed, rigging is almost synonymous with Nigerian elections. The main aim of election rigging or malpractice is to frustrate the democratic aspirations of citizens who have voted or would have voted into office someone instead of the victor. These days, votes don't count because come rain, come sun, electoral body must deliver and no one questions their decisions. In fact, the elections conducted in Nigeria have been cruelly contested that the success of the democratic order has been compromised. This ugly electoral malpractice and rigging have a negative effect on Nigeria's democratic future because the trend is increasing instead of reducing. These trends have actually undermined the chances of successful elections and consolidation of democracy in Nigeria.

\subsection{Clarification of key concepts}

Democracy: Although many definitions have been given but there is no agreement on definition. According to Schumpeter (1947), democracy means only that the people have the opportunity of accepting or refusing the men who are to govern them. By this, democracy implies conducting elections and choosing leaders that will represent the majority. Rousseau and Rivero (2003) see democracy as the power of the people as it manifest in ways of thinking, behaving, and organizing that enhance participation in and influence over the decisions affecting their everyday lives. This kind of process can come through, public debate, election and representation-building of consensus and formidable decision-making.

Precisely, democracy is seen as a political system that is characterized of periodic and free elections in which politicians arranged into political parties that engage themselves in a competitive polls to ensure a standing government, where the political right will enable all adult citizens (18 years and above as it applied in Nigeria) to vote and be voted for.

Furthermore, Huntington (1991) sees democracy as a political system which is considered democratic because the most popular candidates are chosen through fair, honest, and periodic elections in which candidates freely compete for votes and in which virtually all the adult population are qualified to vote. This promotes political participation of all adult members. The full participation of the people during electioneering gives the new government a legitimate foundation to govern. Any government against this background will not enjoy legitimacy which gives every government a political support from the people because it is deemed rightful since the support emanates from the people. However, if democracy is all about to choose who should govern the people, then election is one paramount way to select.

Election rigging: Election rigging according to Nwabueze (2003) refers to electoral manipulations which are palpable illegalities committed with a corrupt, fraudulent or sinister motive to influence an election in favour of a candidate (s) 
by way such as illegal voting, bribery, treating and undue influence, intimidation and other form of force exerted on the electorates, falsification of results, fraudulent announcement of a losing candidate as the winner (without altering the recorded results). Election rigging was perfected in the elections conducted in 1964, 1965, 1979, 1983, 1999, 2003 and 2007.

Election rigging connotes any form of undue authority or power that influence and manipulate election result in a dubious way to protect a particular interest against the interest of the generality of the masses. When the interest of the people are articulated in a free and fair election, the government in power tend to enjoy the sovereign legitimacy of the people but election rigging can thwart the interest of the people hence the dubious imposition of an unpopular candidate. The sad end is governments' lack of people's support which is one of the basic principles of democracy.

Election: This facilitates and shapes democracy. Democracy is regarded as the best form of government because its ideology promotes peoples' will. The people have political right to decide who should govern them in a free and fair conduct called 'election'. Therefore, elections constitute an essential principle in liberal democracy. Election in a democracy is very important because it is through which that the expression of the people are shown via legitimacy and leadership succession. According to Dickerson,M.et al(1990) election is defined as a post mortem that investigate the record of office holders whose actual performance may have little to do with promises made when they were previously elected. This is a way of censuring, reposing function in a ruler that is popularly accepted and ejecting an unpopular leader. This method shuns mutiny and chaos in a system hence it reflects peaceful hand-over from one administration to the other so long as the process is devoid of election rigging.

Democratic Consolidation; This implies a democracy that can last for the test of time. This can be assured if those values that made democracy worthwhile are fully institutionalized. Kaur (2007) states that democracy become sustainable when there is credible opposition capable of replacing an incumbent government by offering an alternative outline of politics and strategies that is likely to appeal to the electorate. By the concept of democratic consolidation, it connotes a deliberate political process in a polity by which democracy is "so broadly and profoundly legitimatized among its citizens that it is very unlikely to break down" (Ouyang, http://www.oycf.org/perspective/6-063000). This is democracy that will come and stay and which cannot come to an end suddenly or abruptly through unconstitutional acts such as military coups or dictatorships. To consolidate democracy, it needs behavioural and institutional changes that normalize democratic politics and narrow its uncertainty. Democratic consolidation is an off-shoot of good governance which encompasses accountability, security of human rights and civil liberties, devolution of powers and respect for local autonomy, which all constitute a challenge to democratic regimes (Eyinla, 2000: 22). In fact, democratic consolidation can be measured by the percentage of voters in a country who consider democracy as an indispensable way of life and are ready to go every length to protect it.

\section{Elements of Election}

In a democracy, elections serve as an important mechanism and viable means that ensure orderliness in the process of leadership succession and change. It gives legitimacy and political authority to every administration. Elections play dominant roles in a democracy and these roles are hugely circumscribed in terms of portraying the popular will, inculcating political changes and actualization of regimes legitimacy. Schumpeter (1947) notes that democracy ensures that the people have the opportunity of accepting or refusing the men who are to rule them, this means that democracy is all about conducting elections and choosing political leaders.

Elections ensure how popular a government is and it reveals the social pact that exist between the govern and the governed and this illustrates the basis of political authority, legitimacy and citizens' obligations. It also helps to shape and sharpened political accountability between the governors and governed via reciprocity and exchange. As Sandbrook (1988) posit: Elections and the struggle for power are essential because it gives the oppressed classes the chance to put the question of alternative ideologies on the agenda and therefore constitute an important stage in the socialist quest to extend democratic control to the social and economic as well as political sphere.

However, for elections to thrive there should be the establishment of a well defined, competent, relatively independent and non-partisan electoral body that will be responsible for the conduct of elections. There is need for the existence of impartial judiciary that will interpret electoral laws and as well as adjudicate on electoral matters. Mass media devoid of influence from the politicians should be instituted together with police force that will help supervise the conduct of an election. Jinadu, (1995) and Adejumobi, (1997) concur that: There should be electoral laws guiding the conduct of an election, organization of political parties, voters' registration, nomination of candidates for elective public office, balloting , ballot-counting and the declaration of election results as this will give credence to the success of elections.

\subsection{Ways of Rigging an Election}

Election rigging has taken many dimensions in Nigeria. Observers have identified some ways by which elections are rigged in Nigeria. In his observation, Ibrahim (2007) identifies some forms of electoral fraud as follow: 
1. Illegal printing of voters' cards;

2. Illegal possession of ballot boxes;

3. Stuffing of ballot boxes;

4. Falsification of election results;

5. Illegal thumb-printing of ballot papers;

6. Infant voting

7. Compilation of fictitious names on voters' lists;

8. Illegal compilation of separate voters' lists;

9. Illegal printing of forms used for collection and declaration of election results;

10. Deliberate refusal to supply election materials to certain areas;

11. Announcing results in places where no elections were held;

12. Unauthorized announcement of election results;

13. Harassment of candidates, agents, and voters;

14. Change of list of electoral officials;

15. Box-switching and inflation of figures.

Added to the above, some politicians who have upper-hand in the government, in an attempt to win an election by all means may call for an illegal arrest and detention of their opponents on or before the Election Day. This as a result, might render mobilization of votes by his opponents very limited. Influential politicians sometimes hire thugs who will rigmarole the streets shooting sporadically in the air at polling centers to scare away genuine electorates who will in return run for their dear lives allowing these thugs to take away the stuffed ballot boxes and replaced it with empty ones.

In the other hand, genuine voters' holders are subjected to fear that election is going to be a do-or-die and the peace loving Nigerians would prefer to stay at home to facing any wanton intimidation and this will enable politicians the chance for massive rigging. Finally, security agents nowadays serve as an instrument for an election rigging. Unfortunately, security agents who are suppose to serve as a symbol of peace and order sometimes collide with some politicians in election rigging. They will scare away voters by carrying out a massive arrest at the targeted locations so as to allocate more votes for their influential masters.

\section{The Historical Review of Election Riggings in Nigeria}

After Nigerian independence in 1960, the hope and aspiration of Nigerian to attain nationhood began to fade evident emanating from the way elections were conducted after the departure of the colonial British. The two democratic regimes of the first and second republics were dents on democracy. As at this period, the concept of democracy in Nigeria context was seen as a miscarried concept analyzed only by the political elites as it suits their interests. This was shown in the election conducted in 1964 which witnessed a rampant election rigging and rampaging manipulations.

\subsection{The General Election of 1964/ Western Election of 1965}

After the 1964 general election, there was upheaval from the election conducted in the west as a result of some manipulations and this necessitated for a fresh election in 1965. The 1965 Western election revealed that electoral officers were colliding with the political party that was favoured by the federal government to disallow voters from the opposing political party from filling their allocated nomination papers. The nature of the election rigging was summarized by Dudley (1981), Anifowose (1982); Post and Vickers (1973) thus: Akintola and his party (NNDP), with the Federal government's support, carried out a staggering horrific rigging machinery, thuggery, obstruction and punitive control to give NNDP an overwhelming victory.

Frankly, in this region, the popular party was Action Group (AG). The people of the region saw Obafemi Awolowo as their political godfather and resolved to deliver the region for his party. They rallied against Chief Samuel Akintola (a Westerner) with federal government support and a flagbearer of Nigerian National Democratic Party (NNDP) but had a power tussle with Chief Awolowo. The ruling party (Northern People's Congress) supported Akintola via massive rigging and voted Chief Obafemi Awolowo's Action Group (AG) out. . Dudley (1982) notes that the Deputy Leader of the NNDP and also Deputy Premier of the west, had in fact said before the elections that whether the electorate voted for the NNDP or not, NNDP would win the elections. 
Even though people clearly rejected the government and candidature of Akintola at the polls and massively voted for the opposition party (Action Group). As a result, Akintola government intervened publicly with the election results. Ademoyega (1981:21-22) notes that in very many cases, AG candidates who held certificates that they were duly elected in their constituencies later heard their names mentioned as defeated candidates through governmental news media.

There was disappointment among AG members as their attempt to vote Akintola and his party out of office failed, they resorted to widespread violence in many parts of the regions and the country, which resulted to military takeover of government in January 15, 1966 and this ended the first democratic experience in Nigeria.

\subsection{The General Election of 1979}

The second republic brought with it a constitution (1979 constitution) which provided for various political parties to arrest back the country from the military that had existed since 1966 after thwarting the first republic of 1963 in a coup d'état led by Major Kaduna Nzeogwu in 1966. This measure was taken to restore back yet a democratic administration and a presidential system of government that will replace a parliamentary system as this was seen by Nigerians as the best option for the country.

The election (1979) was the second immediate testing ground for democracy after a thirteen-year military administration which lasted from 1966-1979. Five different political parties competed and they are; Nigerian Peoples Party (NPP), Unity Party of Nigeria (UPN), People's Redemption Party (PRP), Great Nigerian People's Party (GNPP) and lastly, National Party of Nigeria (NPN) which eventually produced the first executive president in Alhaji Shehu Shagari. However, this election was a replica of the previous elections carried out in the country. In this election (1979), the military administration in power played a dubious role in determining the election outcome and they subverted the result and enthroned an unpopular candidate through election rigging. As a result, Awolowo challenged against the election outcome but the court nullified his effort.

\subsection{The General Election of 1983}

In 1983, another election was conducted and NPN which was the incumbent government won using a tremendous rigging and violence like was in the first republican elections and this eventually generated so much violence in the various states to rationalize the military takeover of December, 1983 and as a result, brought to the end of second republic.

However, 1979 election brought some reliefs as regards to how freer it was, comparing with 1964/1965 elections but 1983 election uttered the rewarding standards set by 1979 election. To support this argument, Tijani (1986:15) notes: A massive collusion involving the NPN, the FEDECO (The Federal Electoral commission), the police and some sections of the judiciary had produced governments that could not claim legitimacy by dint of even the most rudimentary requirement of a bourgeois democracy. Pointing the level of fraudulent the election was, Kurfi (2005) notes: All sorts of strategies and stratagems including manipulation of the ballot or "rigging" were employed in order to win election. Each of the opposition parties used its local power of incumbency to retain power and /or to improve its position vis-à-vis other contenders. However, federal might was used to dislodge state governors in Anambra, Oyo, Kaduna, Gongola and Borno states, thus raising NPN's tally of governorships from seven to twelve states, reversing the power structure existing before the election when opposition parties had twelve against NPN's seven governors.

There was this scenario in Ondo state between Chief Akin Omoboriowo (National Party of Nigeria gubernatorial candidate) and Chief Micheal Ajasin (Unity party of Nigeria gubernatorial flag bearer). The former was declared the winner by Electoral Commission (FEDECO) with 1,228,891 votes as against 1,015,385 votes credited to the later. However, base on the election count, the verdicts from the Federal court of Appeal and the Supreme Court as shown in the certificates of results duly signed by the assistant returning officers, party agents as well as oral witnesses from returning officers indicated that the true results were 1,563,327 votes for Chief Ajasin and Chief Omoboriowo scored 703,592. Evidence from these verdicts showed that Chief Omoboriowo's scores were inflated by 523.389 votes leaving that of Chief Ajasin decreasing by 547,942 votes. Report showed that the fabrications of the figures were carried out by the deputy returning officer. Nwabueze (2005) noted that Chief Michael Ajasin was declared by the court to have duly elected the governor of Ondo state. The 1983 election is characterized as one the most corrupt elections ever conducted in Nigeria. Iyayi (2005:2) captions this argument, when he states that election include massive electoral frauds, the conception and practice of politics as warfare, the lack of continuity in the political platforms used by members of the political class, high levels of opportunism and thus a low level of commitment to the different variants of right-wing political ideologies that characterize the political class, the objectification of politics, and the mobilization of ethnic identities as the basis for defining the legitimacy of claims to political power. The Babalakin Commission of Inquiry into the 1983 elections correctly argued: 
The nature of politics and political parties in the country is such that many men and women of ability and character simply keep out of national politics. For the most part, political Parties are dominated by men of influence who see funding of political parties as an Investment that must yields dividends. (Federal Republic of Nigeria, 1986:348).

\subsection{The General Election of 1993}

In 1993, the military government headed by Gen. Ibrahim Badamosi Bbangida introduced two political parties namely; Social Democratic Party (SDP) and National Republican Convention (NRC). The election for these two political parties was seen by Nigerians as the only hope to eradicate military administration in Nigeria's body polity and went to the pools massively in June 12, 1993 to support democratic emergence. The introduction of two-party was a good move from the military in power because all ethnic interests have no choice than to accommodate themselves in either of the parties, and the two parties became essentially representative of all ethnic groups. This made the electorates to fully express their wishes by voting for their candidates on the ground of competence than voting along strictly ethnic considerations. Unfortunately, the election that was considered as the end of military dictatorship and a departure from the previous elections conducted, still had its negative impact ranging from election rigging or what Moshood (2009) summarized as: A new phase to election rigging in Nigeria when the military president Ibrahim Babangida, could not achieve his mission at the poll, he publicly manipulated i.e. rigged people of their interest by annulling the election results considered as the most free and fair in the history of Nigeria's election. The annulment of this election's result threatened the political stability and unity of Nigeria and pushed the country back to deep-seated political turmoil and further military authoritarianism. Amidst the tension that gripped the country resulting from political instability that was emanated from the winner of the said election who threatened mutiny if not given mandate in a election he won with great margin, General Ibrahim Babangida stepped aside and handed over the government to an Interim government led by Chief Ernest Shonekan but this was a mere gimmick to usher in another military government as General Babangida's second in command, General Sani Abacha dethroned the Interim government and ruled until he died in power.

\subsection{The General Election of 1999}

The 1999 general election came up with three political parties; Peoples Democratic Party (PDP), All Peoples Party (APP) and the Alliance for Democracy (AD). APP and AD came into alliance and fronted Chief Olu Falae who competed with PDP flag bearer, former military Head of state, Chief Olusegun Obasanjo who later won the election.

Before this election, the military has promised lots of transition but ended up transferring power from one military regime to the other. In fact, the polity had been damaged that people no longer show interest in politics due to three decades of military dictatorship and the people of South-west (Yoruba) extraction were not happy that their son (Abiola) was denied the chance to rule the country in an election conducted in June 12, 1993 which he won with great margin. They saw it as a device from the federal government to stop a Yoruba man from ruling the country. The outgoing military who wanted to settle the above scores, released Obasanjo who was then in detention for an alleged attempted coup and presented him as the sole flag bearer of Peoples Democratic Party (PDP). Obasanjo, who also come from Yoruba, did not attract support from his people because he was picked by the military to run for the election. This made his people accused him of representing the interest of the military oligarchy. The South-west rather rallied support for Olu Falae but Obasanjo later emerged the winner in an election that was seen as a mirage and as a result was not taken serious. The lackadaisical attitude shown towards the elections by Nigerians gave the military junta the free hand to manipulate the election and handed power to the person the hierarchy wanted.

\subsection{The General Election of 2003}

The 2003 election brought some fresh hope to Nigerians because the previous election handed over power from military regime to a civilian regime. Because Nigerians were in desperate need for a democratic consolidation and haven assured by the military that power would be relinquished to a civil administration, the game this time, took a different look in that many were desperate for a political power having seen the kind of money that accrue from politics. This quest for money prompted the incumbents to clinch onto power for more tenure. Though Aina (2006) states that elections were adjudged as greatly flawed by the International observers, it presented in the history of Nigeria politics the first peaceful civilian transition in Nigeria.

However, the election was not without rigging judging from the reports gathered. European Commission which observers rampant election-related malpractice in a number of states in the Middle Belt, the South East and the South -South (European Commission, 2003:42).A Commonwealth Election Observer, Stuart Mole who was an eye witness in the Niger-Delta reveals that the election outcomes were fixed. He notes that while voter turnout for the April 2003 elections was very low in many polling stations, with some polling booths not opening till $2.00 \mathrm{p} . \mathrm{m}$. and closing before 5.00p.m., the election results declared for most constituencies indicated a 90-100 percent voter turn-out (Mole, 2003:427). Added to this, 
Most extraordinary of all, this apparently phantom election recorded extraordinary high turnout figures generally in excess of 90 percent. In Tai district, where we had seen few voters and where the polls had only opened for a few hours, turnout was recorded at an incredible 99.6 percent (and the Peoples Democratic Party (PDP) share of the vote at 99.2 percent). Clearly, widespread voter intimidation had accompanied massive electoral fraud.(ibid). Ogunsanwo (2003:15) remarked on the conduct of the 2003 elections, one thing was unique in the 2003 election. The Independent National Electoral Commission was genuinely not in control. Human Rights Watch which monitored the election and asserted that: Rigging, violence and intimidation were so pervasive and on such naked display that they made a mockery of the electoral process. $\{\ldots\}$ Where voting did not take place, many voters stayed away from the polls. They were frightened off by a pre-election period that saw more than 100 people killed in election related clashes. By the time election ended, the body count has surpassed 300 (Human Rights Watch, 2003). In his speech, Iyayi (2007) noted that Transition Monitoring Group described 2003 election thus: “ ....Twenty-nine of the registered political parties that either contested or did not contest the elections have variously rejected the results as announced by the INEC (Independent National Electoral Commission) declaring the results a fraudulent. Some political parties and their candidates decided to challenge some of the results before the various Election petition tribunals and have gone ahead to do while others declared "mass action" to pressure a government without popular candidate to quit power. Abubarkar Momoh describing the latest Nigeria democracy crippled with rigged elections and other forms of manipulations, dubbed it "presidential Authoritarianism". In his words: It is questionable whether what we had in 1999 and 2003 could be rightly qualified as election and not selections or better still allocation of positions. The( ruling ) Peoples Democratic Party (PDP) using the (so called) Independent National Electoral Commission (INEC) and the Nigerian Police to (sic) share out votes to contestants. Party primaries were mere impositions of godfather's candidates. And they were then allocated votes by INEC (Momoh, 2005.51).

\subsection{The General Election of 2007}

The 2007 election marked the first time when a third consecutive presidential election took place and the first time when one elected leader succeeded another in the history of Nigeria's election. Amidst the tension that engulfed the country via delay in reviewing the constitution to give real autonomy to the electoral commission by the National Assembly, Obasanjo and his vice Atiku accusing each other of corruption, agitation for more tenures from the southern politicians while northern politicians insist that power must move back to their region, or the persistent disturbance from the Niger Delta militants to control some oil wells located in their states. Many political parties registered, the struggle for who should control the government gained momentum and this gave room for various presidential aspirants with the motives of perpetrating all forms of maneuvers to dethrone the leadership of Peoples Democratic Party (PDP).President Obasanjo who failed in his bid for third term tenure, handpicked his successor (late president Umaru Musa Yar Adua) in a PDP convention and left other aspirants vying for the same seat disappointed. Earlier on, some PDP members who had intention to vie decamped to some other political parties and this made the election even fierce as killing of political opponents mount. This of course did not stop without election rigging since it was a carryover of the 2003 election which employed all kinds of riggings.

2007 election was not far from previous elections conducted in Nigeria. This time around, the election rigging went scientific as the Electoral bodies made electronic voting their benchmark. In spite of the promise from INEC chairman that the election will be free and fair, local and international monitoring team categorized the election a rigged one, in fact, as the most damning kind of election ever conducted anywhere in the world. In his speech, Iyayi (2007) notes: The April 2007 general elections surpassed the 2003 and 2004 elections in the level of fraud, violence, rigging, criminality and complicity by the various organs of the state in the electoral farce that occurred. Human Right Watch reported that 'in several key states, the Nigerian government failed completely in its obligation to conduct free and fair elections'. The 59 member International Republican Institute concluded that the first three parts of Nigeria's April 14 and April 21 election process fall below the standard set by previous Nigeria elections and international elections'. The remaining part of the election process was the determination of election disputes in the election tribunals and the courts. The challenges from some of the election outcomes have seen some been upturned while fresh elections were declared in some states like; Ekiti, Edo, Oyo, Benue and among others. Recently, one of the leading newspapers in Nigeria, The Nation, reported through Adekunle Jimoh in 15th October, 2010 that a governorship aspirant (Dr. Kayode Fayemi) who contested in 2007 was returned as the governor of Ekiti State having been rigged out in a re-election he won with 105,631 votes against Olusegun Oni’s 95,176, who maneuvered the contest via election rigging and this also affect many other states with cases of election riggings.

\section{Election Rigging: Bane to Nigeria's Democratic Consolidation}

Government is for the majority. This is evident in the popular definition of democracy by Abraham Lincoln.”Democracy is the government of the people, by the people and for the people”. Meaning a government where the majority rules. As a result of this conceptual definition, in Nigeria context, anyone who is 18 years old and above 
has the civic right to participate in electioneering. Democracy can be consolidated if there exist popular participation. Participation is meaningful when the votes of these participants count but not when their votes are subverted for the interest of the few. When the majority did not participate in choosing who should represent them, it is not democracy but the government of the few (oligarchy). Where elections are rigged by the few, it does not represent democracy and consolidating democracy in such an environment is very difficult.

Election rigging since independence in 1960 has delayed Nigeria's hope for a consolidated democracy. For democracy to be consolidated, the government in power must be legitimate. Legitimacy is the belief in the rightness and appropriateness of the ruling regime and the government and their policies by the populace (Dahrendorf, 1996). The ruling government cannot command legitimacy through the use of force; it's the right of the people to grant or withdraw legitimacy from governments (Nwosu, 1976:6) and this varies from time to time depending on how satisfied citizens enjoy from the government in power (Dare, 1975). In Nigeria, election riggings have failed to produce a government that will be popularly acceptable. This is because some of the leaders that emerged victorious in her elections as we analyzed in this work found themselves in the corridors of power using all forms of manipulations and this restricted the chances of true candidates from winning the election even though they are people's choice. When this unpopular candidate is elected, the people will be reluctant to support his administration as they feel that the government is a stolen mandate. Any government that assumes office against the majority votes lacks the legitimacy of the moral authority that popular mandate enjoys. Democracy cannot be consolidated where a candidate is imposed against the choice of the people and a government instituted without people's acceptance will not succeed.

Election rigging has instigated for the emergence of bad politicians who want power by hook or crook. During electioneering, these politicians will employ every means to clinch onto power and the installation of these candidates result in corruption and capital accumulations. Obia (2006) observes the implication thus: It has been contended that as a result of electoral fraud the people lost faith in the electoral process more so in opposition politics. One of the cardinal reasons why elections are held is to enforce government responsibility and accountability but electoral fraud strips election of its essence as an instrument of holding leaders accountable to the electorate. A government who rigged itself into power will not have any moral justification to perform hence it has no interest to satisfy anyone. A government is instituted to promote fundamental human rights but where a government does not care about the welfare of her citizens but dwells in accumulation of private wealth, democratic consolidation suffers as government responsibility and her accountability to the electorates would have been rendered useless.

Democracy as Abraham Lincoln defined it is for the people. This means that government cannot exist without the people. Unfortunately, election riggings over the years have aided to the violation of the principle of fundamental human rights which A.V Dicey advocates as the right to life for every citizen born in a country. Many political conflicts in Nigeria which claimed citizen's right to life have emerged via election riggings. Osaghae (1998: 45) captions this fact when he states: The parties employed violent tactics, which sometimes involved the physical elimination of opposition candidates. This was conspicuous in 1964 elections when opposition candidates were harassed, prevented from campaigning and even the filing of nomination papers was made impossible. More of these incidents were reported from the northern and western regions, which were in the thick of political competition. Some political godfathers have hired assassins to eliminate their opponents. Struggle to stifle ballot boxes at some polling stations have claimed the lives of so many Nigerians. The laws guiding the principles of a democratic government have been perverted rather than consolidated when we consider how loose the law is, in checkmating the activities of those who violate human right (right to life) in the name of election rigging.

\section{Recommendations and Conclusion}

Freedom to vote and participation, leadership responsiveness, accountability and legitimacy hold tenaciously on free and fair elections. Where there is free and fair elections, the citizens will appreciate the values of democracy. What we witness in Nigeria is imposition of wrong candidates on the people's right to choose candidates of their choice, lack of people's participation, absence of leadership responsiveness, accountability and legitimacy. These factors have raised agitations for the creation of electoral body that will look into fraudulent act in elections.

As a result of massive rejection of the 2007 election results, the government created election petition tribunals whose function is to examine some election petitions and give verdict to same. Experience from their functions have shown that this reform has not been able to meet the desired goal because, when a fresh election is called in place of the previous one cancelled, the same thieves that initially stole the mandate of the electorate will come back with even greater coercion this time to perfect their perfidy. Even as that, the implementation of this body, have witnessed some success stories like removing a candidate who assumes leadership position dubiously and install the right candidate. Examples can be drawn from the case of states like; Edo State, Anambra State, Oyo State, Benue State and the recent, Ekiti State, where Dr. Kayode Fayemi was returned as the governor of the state after being rigged out in re-election he 
won. Despite the people's commitment to achieve the above objectives, some politicians still indulge in election rigging.

Since 1964 till 2007, election rigging has been a threat to democracy. Unfortunately, some politicians who carried out this dastardly art have gone scores free. In as much as politicians are not nailed in their previous manipulation of elections, the future politicians keep re-strategizing manipulations for subsequent elections, thereby making election rigging inevitable in Nigerian politics.

In order to reduce this menace, there is need for legal restriction on these politicians who perpetrate this ugly art. When people's mandate is perverted against their will by some politicians, it is stealing of highest order. This is massive stealing and it needs the same penalty places on a criminal. Any candidate or group of persons who assume political positions using election rigging and are proved guilty by the Election Tribunal, will not only nullified of their candidatures, relinquish their positions but fined. The former President of Nigeria in the second republic (Alhaji Shehu Shegari) was banned from participating in politics for excess embezzlement of public fund. We are of the opinion that for a sustainable democracy to fully take place in Nigeria, our current democracies need some surgical operations like; imposing fine on the person or persons in some cases where they have illegally occupied such positions; suspend unscrupulous politicians from politics hence they thwarted the efforts of patriotic Nigerians in consolidating democracy via election rigging.

In Nigeria's quest to consolidate democracy, there should exist strong opposition party or bodies. In Liberal democracies, opposition parties put constructive pressure on the ruling political party and serve a watch-dog role. It is unfortunate that the Peoples Democratic Party (PDP), the ruling party in Nigeria has been hostile to opposition parties, mass media and civil society organizations. To command loyalty from opposition parties or critics, they have resorted to using appointment to break the ranks of other political parties. When these men from opposition parties held such appointments, they find it hard to resist the lure of carpet-crossing the ruling party (Epia 2003: 11; Obia 2006). The ruling party (PDP) shut down African Independent Television (AIT) because of its critical stance on the third term agenda. The same hostility from the government against the opposition made them deny the people free access to information of government activities as debated in the Information Bill.

Worse of it all, some wicked politicians or parties have indulged in the elimination of strong opponents. This in return made the opposition weak and dead scared to push on and some credible members who would have run will hide their dear lives least should they be the next target. To stop this ugly situation, a death sentence should be handed to any contestant found guilty of initiating or carrying out elimination of his opponents because he wants to gain upper-hand in the election. It will be wise to hit anyone who eliminates his opponent because of political position to face the penalty as applies to someone who commits murder.

There is need to reduce the materialized nature of Nigerian politics if the country want to attain consolidated democracy. It is true that the financial stakes in an election these days have gone to the level that only those who have tasted power previously or work in the government for so many years and accumulate more money are capable of backing their political claims. From 1999 to 2007, we witnessed politicians claimed to have mapped out billions of Naira (Nigerian Currency) on elections. These billions will be spent in order to win election at all cost.

The implication is that credible candidates who don't have the financial muscle to challenge these wealthy politicians will either drop out or hide under the mercy of godfathers. Obviously, politics of godfatherism has raised its ugly head in Nigerian politics because they (godfathers) raise money to sponsor candidates (godsons) who will be answerable to them instead of the masses. Obia (2004) notes that the practice of godfatherism smacks of political criminality and subverts the values of democracy and good governance. This relationship between the godfather and godson encourages the office holder (godson) to give no regards to the values of good governance which would have promoted transparency and accountability.

Nigerians still have a chance in April, 2011 to right the wrongs as another general election will be conducted. Forums have to be created to re-orient the electorate on the need to embrace political culture that will help to eradicate all forms of election rigging considering the ugly effects of it in our body politic. It is high time we stopped hiding from exercising our civic right, Nigeria is ours and we must do everything to protect her interest. We need a free and fair election which will install a candidate widely accepted by the people, choose our representatives in a free and fair contest, and when all these factors are in place, the people are likely to obey laws, respect the rights of others, accept conventional means of political participation and more importantly, accept the principles and values of democracy which will institutionalize democratic consolidation.

\section{References}

Adejumobi, S. (1997). The Two Political Parties and Electoral Process in Nigeria, 1989-1993.”In the State and Democracy in Africa (G. Nzongola Ntalaja and M. Lee, eds.) Harare: AAPS. 
Adekanye, J.B. (1990). Elections and Electoral Practices in Nigeria: Dynamics and Implications. The Constitution: Journal of Constitutional Development. Vol.5 No.2.

Ademoyega, A. (1981). Why We Struck: The Story of the First Nigerian Coup. Ibadan: Evan Publishers

Aina, A.D. (2006). Party Competition and the Sanctity of Electoral Politics in Nigeria: Unresolved issues revisited (p.54).

Anifowose, R. (1982). Violence and Politics in Nigeria: The Tiv and Yoruba Experience. New York, London, Lagos and Enugu: NOK.

Dahrendorf, R. (1996). On the Governability of Democracies, in Benard Brown and Roy Macridis, Comparative Politics: Notes and Readings, 8th Edition. Belmont: Wadsworth.

Dare, L. (1975). Nigerian Military Governments and the Quest for Legitimacy, January 1966- July 1975, Nigerian Journal of Economics and Social Studies. 17(2) 5-118.

Dudley,B.(1981). The Nigerian Elections of 1979: The Voting Decision. Journal of Commonwealth and Comparative Politics, Vol. XIX, No.3.

Dudley, B. (1982). Introduction to Nigerian Government and Politics. Macmillan: Nigeria.

Epia, O. (2003). Where is the Opposition? Thisday, August 19, 2003,p.11.

European Commission, Nigeria. (2003). European Union Election Observation Mission Final Report.

Eyinla, B. (2000). The Political Transition and the Future of Democracy in Nigeria. Political Science Review Vol.1 No.1

Federal Republic of Nigeria. (1986). Report of the Judicial Commission Inquiry into the Affairs of Federal Electoral Commission, 1979-1983.

Human Rights Watch. (2004). Nigeria’s 2003 Elections: The Unacknowledged Violence. New York

Human Rights Watch. (2005). Rivers and Blood: Guns, Oil and Power in Nigeria’s Rivers State. New York.

Huntington, S.P. (1991). The third wave: Democratization in the late twentieth century. Norman: University of Oklahoma Press.

Ibrahim, J. (2007). Nigeria’s 2007 Elections: The Fitful Path to Democratic Citizenship.

Ihonvbere, J. (1989). Underdevelopment and Crisis in Africa. Lagos: JAD Publishers Ltd.

Iyayi, F. (2005). Elections and Electoral Practices in Nigeria: Dynamics and Implications, The Constitution: Journal of Constitutional Development. Vol.5 No2.

Jinadu, A. (1995). Electoral Administration in Africa: A Nigerian Case. Study under the Transition to Civil Rule Process. In the Political Economy of Nigeria Under Military Rule, 1984-1993 (S. Adejumobi \& Momoh, eds.). Harare: SAPES.

Jinadu, L.A. (2007). Historical Analysis of Elections and Election Management in Nigeria. Paper prepared for presentation of the Civil Society Organisation meeting on electoral reform organized by the Open Society Initiative for West Africa (OSIWA) in Abuja, Nigeria, Oct. 19.

Kaur, S. (2007). Institutional Development as a Challenge to Democratic Sustenance in Nigeria. International Studies. 44; 217. Doi: 10.1177/002088170704400302 , http://dx.doi.org/10.1177/002088170704400302

Kurfi, J. (2005).Nigerian General Elections, 1951-2003: My Roles and Reminiscences. Abuja: Spectrum Books.

Mole, S. (2003). The 2003 Nigerian Elections: A Democratic Settlement? The Round Table No. 370. Pp. 423-28.

Doi:10.1080/0035853032000112566, http://dx.doi.org/10.1080/0035853032000112566

Moshood, B.A. (2009). Election Rigging and Governance in Nigeria: An Appraisal. LASU Journal of Humanities. Vol.6

Momoh, A. (2005). Democracy or Good Governance? Making sense of Disempowerment in Nigeria (i), in The Guardian August 19.

Nwabueze, B. (2003). Nature and Forms of Election rigging. Retrieved from nigerdeltaworldcongress.org

Nwabueze, B. (2005). Nature and Forms of Election Rigging. www. Nigerdeltacongress.com

Nwosu, H. (1977). Political Authority and the Nigerian Civil Service. Enugu: Fourth Dimension.

Obia, V. (2004). Godfathers are Political Criminals, says Falana. Daili Independent, February 16, 2004. 
Obia, V. (2006). The Failing Opposition. Sunday Independent, February 5, 2006, p.B9-10

Ojie, A.E. (2006). Democracy, Ethnicity, and the Problem of Extrajudicial Killing in Nigeria. Journal of Black Studies 36; 546. Doi:10.1177/0021934705280304, http://dx.doi.org/10.1177/0021934705280304

Osaghae, E.(1998). Crippled Giant: Nigeria Since Independence. London: Nigerian Political Science Association.

Post, K. \& Vickers, M. (1973). Structure and Conflict in Nigeria. 1960-1966. London: Heinemann.

Rousseau, D.M. \& Rivero, A. (2003) Democracy, A way of Organizing in a Knowledge Economy. Journal of Management Inquiry. SAGE Publications.

Sandbrook, R. (1988). Liberal Democracy in Africa: A Socialist Revisionist Perspective. Canadian Journal of African Studies. 22 (2). Doi:10.2307/485904, http://dx.doi.org/10.2307/485904

Schumpeter, J.A. (1947). Capitalism, socialism, and democracy. New York: Harper and Brothers.

Tijani, K. (1986). Democracy, Accountability and the State of the Nation's in Abubakar S.M and Edo, T. (eds.), Nigeria: Republic in Ruins, Zaria: Department of Political Science.

The Nation Newspaper of 15th October, 2010.

Transition Monitoring Group. (2003). Do the Votes Count: Final Report of the 2003 General Elections in Nigeria. Abuja. 